\title{
GENETICAL STUDIES ON COMBINING ABILITY FOR YIELD AND ITS COMPONENTS TRAITS IN HYBDRID RICE UNDER NORMAL AND SALINE CONDITIONS \\ Abd El-Maksoud, M. M. ${ }^{1}$; Z. M. El -Diasty ${ }^{1}$; M. S. Hamada ${ }^{1}$; A.E. Draz $^{2}$ and M.M.Shehab ${ }^{2}$ \\ 1) Genetic Dept., Fac. of Agric., Mansoura University, Egypt. \\ 2) Rice Res. and Training Center (RRTC), Sakha, kafr El-Sheikh, Egypt.
}

\begin{abstract}
In this study, an effort was made to identify good parents and nature of gene action governing yield and its components characters of rice under normal and saline environmental by Line (three cytoplasmic male sterile) $x$ tester (three restorers) analysis. In the present study, the mean square due to genotypes, parents, crosses and parent vs crosses revealed highly significant variations at locations, years and their combined analysis over locations through years. The interactions of genotypes, parents and crosses by years and locations were highly significant for all grain yield and its components traits except 1000-grain weight trait which revealed insignificant interaction over the years. On the other hand the mean squares resulting from the interaction of genotypes, parents and crosses by years $\times$ locations were insignificant in all studied traits except number of grains / panicle and the number of filled grains / panicle traits which showed highly significant.

GCA for lines and testers and SCA for Lines $x$ testers were highly significant under all environments and combined analysis for yield and its components traits. Similarly, the genetic variance of interaction of lines and testers by years and locations were highly significant. But the mean squares of interaction of lines and testers by years $x$ locations were often insignificant for all traits except number of grains / panicle and number of filled grains / panicle traits which revealed highly significant. Parents with high $\mathrm{x}$ high or low $\mathrm{x}$ high general combining ability GCA effects gave the best heterotic combination like the 1R70368A / Giza181R Meanwhile, the CMS line IR70368A was the best female general combining ability for most of studied traits, while, the restorer lines Giza181R and Giza182R were the best testers capable of to combine their genes with the lines for the most studied traits. Also, the cross combinations IR70368A x Giza 181R and IR58025A x Giza 182R showed high SCA effects for most studied traits and considered as the best combinations. The results showed that all yield and its components traits were largely governed by additive gene action except number of panicles / plant which was governed by non-additive gene action, indicating that the additive variance plays the main role in the inheritance of these traits. Furthermore, the magnitude values of additive by years, locations and years $x$ locations interactions were positive and larger than non-additive interactions for all yield traits. Heritability estimates in the narrow and broad senses were close together in value for most yield and its components traits, indicating that the additive genetic variance plays the master role in the inheritance of these traits.
\end{abstract}

\section{INTRODUCTION}

Rice (Oryza sativa, L.) is considered as one of the most important cereal crops not only in Egypt, but also all over the world. In Egypt, the annually cultivated area by rice is almost more than $20 \%$ of the total area. 
According to the statistics of the Ministry of Agriculture in 2009, the total cultivated area of rice was about 1.2 million feddan all of it under irrigation. During the past 20 years, Egypt's Rice research program has succeeded in raising the national average rice yield more than $70 \%$, from 2.4 million ton national production for the base period (1984-1987) by a steady increase annually to reach its maximum 4.92 million tons of paddy rice in 2009 (Proceeding of 2009, Researcher at RRTC). In spite of the great progress achieved in rice productivity in Egypt, we need to make another breakthrough to increase rice yield per unit area and unit time by raising the national average yield more than 15\%. It is hard to achieve through inbred varieties because we have improved commercial varieties with superior genetic background (El-Mowafi et al., 2009).

Salinity effects on plants are complex. The general effects of salinity are the results of both osmotic and ionic stresses (Greenway and Munns, 1980). The initial and primary effect of salinity, especially at moderate salinity concentrations, is due to its osmotic effects (Munns and Termaat, 1986 and Jacoby, 1994). At the whole plant level, ion concentrations in plant tissues increase as a result of salinity stress. Ion toxicity or nutrition deficiency will be caused by the overdominance of a specific ion (Bernstein et al., 1974). The measurable or visible effects of salinity on plants can include reduced growth rate, damage of meristems in growing shoots, reductions in yield components, or typical symptoms of nutritional disorders under osmotic and ionic stress. Grain yield reduction of rice under stress of root-zone salinity can be caused by injuries at both seedling and maturity stages. In most commonly cultivated rice cultivars, young seedlings were very sensitive to root-zone salinity (Pearson and Bernstein, 1959; Kaddah, 1963; Flowers and Yeo, 1981 and Heenan et al., 1988). Yield components related to final grain yield were also severely affected by root-zone salinity. Primary branches per panicle, panicle length, spikelets per panicle, number of filled spikelets and seed weight per panicle were significantly reduced by salinity (Sajjad. 1984; Heenan et al., 1988 and Khatun et al., 1995).

Line $x$ tester analysis provided useful informations about the nature of the genetic parameters. It also helps in identification of parental lines in terms of their combining ability in cross combinations. This may provide a dependable basis in selecting parents in a hybridization program to get desirable segrgeants. The investigation being reported herein was undertaken with a view to estimate the general and specific combining ability effects under normal and saline conditions and combined for three CMS and three restorer lines useful for hybrid rice breeding program.

\section{MATERIALS AND METHODS}

Line $x$ tester mating design was conducted by using three CMS lines namely IR58025A, IR69625A and IR70368A as a female parents and three restorer lines namely Giza178R, Giza181R and Giza182R as a testers parents (Table 1 ) to obtain $9 F_{1}$ crosses. The trails were conducted in Randomized Complete Block Design with three replications with spacing of 20 $\mathrm{cm}$ between rows and $20 \mathrm{~cm}$ between plants to comprising 9 hybrids and their 
sex parents in the growing seasons of the two years 2006 and 2007 at normal (Sakha) and saline (El-Sirw) conditions. The recommended agricultural practices were followed. Observations were recorded on ten plants taken at random from each test entry replication for No. of panicles / plan, No. of grains / panicle, No. of filled grains / panicle, 1000-grain weight and grain yield / plant. combining ability analysis was carried out as suggested by Kempthorne model (1957).

Table 1: Origin and salient features of the parental genotypes used in this study.

\begin{tabular}{|c|c|c|c|c|}
\hline No & Genotypes & Origin ( parentage ) & Salient features & $\begin{array}{l}\text { Reaction to } \\
\text { salinity }\end{array}$ \\
\hline \multicolumn{5}{|c|}{ CMS Lines } \\
\hline 1 & IR58025 A & $\begin{array}{l}\text { ( IRRI ) IR 48483 A/8 pus } \\
\text { A167-120-3-2//pusA 167- } \\
\text { 120-3-2 }\end{array}$ & $\begin{array}{l}\text { Indica type, late maturing extra long grain, low } \\
\text { amylose content and strong aroma. }\end{array}$ & Moderately \\
\hline 2 & IR69625A & ( IRRI ) & $\begin{array}{c}\text { Indica type, medium early maturing, medium grain } \\
\text { type and medium amylose content. }\end{array}$ & Tolerant \\
\hline 3 & IR70368A & ( IRRI ) & $\begin{array}{c}\text { Indica type, mid. early maturing, medium grain } \\
\text { type and medium amylose content. }\end{array}$ & Sensitive \\
\hline \multicolumn{5}{|c|}{ Testers } \\
\hline 4 & Giza178R & $\begin{array}{l}\text { ( Egypt ) Giza } 175 \text { / Milyang } \\
49\end{array}$ & $\begin{array}{c}\text { Indica- japonica type, medium early maturing, } \\
\text { short statured, tolerance to salinity, short grain, } \\
\text { good grain quality, high yielder and good restorer } \\
\text { for CMS lines. }\end{array}$ & Tolerant \\
\hline 5 & Giza181R & ( Egypt ) IR 24 / IR 22 & $\begin{array}{c}\text { Indica type medium maturing semi- dwarf } \\
\text { resistance to blast excellent, long grain and high } \\
\text { yielder. }\end{array}$ & Sensitive \\
\hline 6 & Giza182R & \begin{tabular}{|c|} 
( Egypt ) Giza 181/IR 39422- \\
163-1-2// Giza 181
\end{tabular} & $\begin{array}{l}\text { Indica type, new released variety, early maturing, } \\
\text { semi-dwarf, long grain, resistance to blast, high } \\
\text { yielder and good fretter for CMS lines. }\end{array}$ & Moderately \\
\hline
\end{tabular}

\section{RESULTS AND DISCUSSION}

\section{Analysis of variance:}

The analyses of variance for yield and its components traits for all genotypes, for each location in each year and their combined data were calculated and the results are presented in Tables 2 and 3, respectively.

The results show that the genotypes mean squares were found to be larger than their corresponding mean squares of the error. However, the results of the F-test cleared that the mean squares of the genotypes showed highly significant values at the two locations through the two years and their combined data. These findings indicated the presence of large variations among them. Similarly, the mean squares of years were highly significant for the traits of grain yield/plant, No.of panicles/plant, No.of grains/panicle and No.of filled grains/panicle and non significant for 1000-grain weight. Therefore, the mean squares of locations were highly significant for all studied traits. Also, the interactions between years $x$ locations were insignificant

The data is clarify that the mean squares of genotypes, parents, crosses and parents vs. crosses showed high significance values for all yield and its component traits at the two locations in the two years and their combined data. These findings indicated overall wide real differences among these populations. 
Abd El - Maksoud, M. M. et al.

Table 2: Mean square estimates from ordinary and line $\mathbf{x}$ tester analysis for yield and its components traits at the two locations through the two years.

\begin{tabular}{|c|c|c|c|c|c|c|c|c|c|}
\hline \multirow[t]{3}{*}{ S.o.v } & \multirow[t]{3}{*}{ d.f } & \multicolumn{4}{|c|}{ No. of panicles/plant } & \multicolumn{4}{|c|}{ No. of grains/panicle } \\
\hline & & \multicolumn{2}{|c|}{ Location 1} & \multicolumn{2}{|c|}{ Location 2} & \multicolumn{2}{|c|}{ Location 1} & \multicolumn{2}{|c|}{$\begin{array}{l}\text { Location } 2 \\
\end{array}$} \\
\hline & & Year1 & Year2 & Year1 & Year2 & Year1 & Year2 & Year1 & Year2 \\
\hline Replications & 2 & $0.035 \mathrm{~ns}$ & $0.089 \mathrm{~ns}$ & $0.072 \mathrm{~ns}$ & $0.155 \mathrm{~ns}$ & $5.408^{\star \star}$ & $18.774^{\star \star}$ & $24.668^{\star \star}$ & $14.254^{\star \star}$ \\
\hline & 14 & & & $29.241^{\star \star}$ & & 2677. & 25 & 299 & $277^{\star *}$ \\
\hline & 5 & $11.223^{\star \star}$ & $33.193^{\star \star}$ & $31.181^{\star \star}$ & $45.463^{\star \star}$ & 2481. & 206 & 3386 & $280^{\star *}$ \\
\hline & 8 & $13.914^{\star \star}$ & $24.240^{\star \star}$ & & & 1617 & $1754.801^{\star \star}$ & $1843.296^{\star *}$ & $1850.017^{\star \star}$ \\
\hline Par & 1 & $48.743^{\star \star}$ & $77.656^{\star \star}$ & $97.801^{\text {** }}$ & $91.560^{\star \star}$ & $12136.385^{\star \star}$ & $11056.640^{\star \star}$ & $10253.938^{\star}$ & $11666.352^{\star \star}$ \\
\hline & 2 & $10.452^{\star}$ & $17.673^{\star \star}$ & 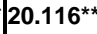 & * $11.923^{\star \star}$ & $1645.684^{\star \star}$ & $1681.753^{\star \star}$ & $1984.067^{\star *}$ & $2186.703^{\star \star}$ \\
\hline Tes & 2 & 13.199 & $40.400^{\star \star}$ & $27.358^{\star \star}$ & 39.54 & $3365.363^{\star \star}$ & 3929 & 4249.62 & $4218.151^{\star \star}$ \\
\hline & 4 & $16.001^{\star}$ & 19.44 & & & & & & \\
\hline Error & 28 & 0.612 & 1.258 & 2.049 & 1.690 & 84.877 & 154.159 & 202.614 & 236.121 \\
\hline
\end{tabular}

${ }^{*}$ and ${ }^{\star \star}$ Significant at $5 \%$ and $1 \%$ levels of probability, respectively.

Table 2: Continue.

\begin{tabular}{|c|c|c|c|c|c|c|c|c|c|}
\hline \multirow[t]{3}{*}{ S.o.v } & \multirow[t]{3}{*}{ d.f } & \multicolumn{4}{|c|}{ No. of filled grain/panicle } & \multicolumn{4}{|c|}{ 1000- grain weight } \\
\hline & & \multicolumn{2}{|c|}{ Location 1} & \multicolumn{2}{|c|}{ Location 2} & \multicolumn{2}{|c|}{ Location 1} & \multicolumn{2}{|c|}{ Location 2} \\
\hline & & Year1 & Year2 & Year1 & Year2 & Year1 & Year2 & Year1 & Year2 \\
\hline Replications & 2 & $3.361^{*}$ & $12.693^{\star \star}$ & $9.521^{\star \star}$ & $7.148^{\star \star}$ & $0.038 \mathrm{~ns}$ & $0.056 n s$ & $0.045 n s$ & $0.003 n s$ \\
\hline Genotypes & 14 & $12558.854^{\star \star}$ & $10208.707^{\star \star}$ & $7197.663^{\star \star}$ & $5957.106^{\star \star}$ & $15.359^{\star \star}$ & $17.529^{\star \star}$ & $13.057^{\star \star}$ & $13.602^{\star \star}$ \\
\hline Parents & 5 & $10234.772^{\star \star}$ & $7335.990^{\star *}$ & $5155.414^{\star \star}$ & $3718.291^{\star \star}$ & $17.169^{\star \star *}$ & $21.942^{\star \star}$ & $16.285^{\star \star}$ & $18.294^{\star \star}$ \\
\hline Crosses & 8 & $2009.167^{\star \star}$ & $1789.815^{\star *}$ & $1393.863^{\star \star}$ & $1234.813^{\star \star *}$ & $13.420^{\star \star *}$ & $13.601^{\star \star}$ & $5.951^{\star \star}$ & $6.008^{\star \star}$ \\
\hline Par. Vs. C. & 1 & $108576.77^{\star \star}$ & $91923.436^{\star *}$ & $63839.307^{\star \star}$ & $54929.523^{\star}$ & $21.823^{\star *}$ & $26.892^{\star *}$ & $53.770^{\star \star \star}$ & $50.891^{\star \star}$ \\
\hline Lines & 2 & $1086.040^{\star *}$ & $1251.183^{\star *}$ & $1664.921^{\star *}$ & $1296.490^{* \star}$ & $20.596^{\star \star}$ & $12.984^{\star \star}$ & $16.500^{\star \star}$ & $17.006^{\star \star *}$ \\
\hline Testers & 2 & $5890.204^{\star \star}$ & $4981.963^{\star \star}$ & $1867.214^{\star \star}$ & $1569.323^{\star \star}$ & $21.285^{\star *}$ & $27.948^{\star \star}$ & $0.442 \mathrm{~ns}$ & $1.173 \mathrm{~ns}$ \\
\hline Lines $x$ testers & 4 & $530.211^{\star *}$ & $463.056^{\star \star}$ & $1021.659^{\star \star}$ & $1036.718^{\star \star}$ & $5.900^{\star \star}$ & $6.735^{\star \star}$ & $3.431^{\star}$ & $2.926^{\star}$ \\
\hline Error & 28 & 109.191 & 101.757 & 153.536 & 126.763 & 0.326 & 0.212 & 0.602 & 0.422 \\
\hline
\end{tabular}

* and ${ }^{* *}$ Significant at $5 \%$ and $1 \%$ levels of probability, respectively.

Table 2: Continue.

\begin{tabular}{|c|c|c|c|c|c|}
\hline \multirow[t]{3}{*}{ S.o.v } & \multirow[t]{3}{*}{ d.f } & \multicolumn{4}{|c|}{ Grain yield/plant } \\
\hline & & \multicolumn{2}{|c|}{ Location 1} & \multicolumn{2}{|c|}{ Location 1} \\
\hline & & Year1 & Year2 & Year1 & Year2 \\
\hline Replications & 2 & $2.031 \mathrm{~ns}$ & $2.765 \mathrm{~ns}$ & $0.686 n s$ & $0.824 \mathrm{~ns}$ \\
\hline Genotypes & 14 & $736.247^{* *}$ & $762.098^{* *}$ & $483.793^{* *}$ & $460.214^{* *}$ \\
\hline Parents & 5 & $558.611^{* *}$ & $534.094^{* *}$ & $243.233^{\star \star}$ & $230.590^{* *}$ \\
\hline Crosses & 8 & $85.018^{\star *}$ & $147.001^{* *}$ & $67.448^{\star *}$ & $82.503^{* *}$ \\
\hline Par. Vs. C. & 1 & $6834.261^{* *}$ & $6822.896^{\star *}$ & $5017.357^{\star *}$ & $4630.011^{* *}$ \\
\hline Lines & 2 & $8.379^{* *}$ & 0.983 ns & $65.099^{* *}$ & $63.776^{\star *}$ \\
\hline Testers & 2 & $277.734^{\star *}$ & $504.759^{* *}$ & $103.287^{\star *}$ & $128.356^{* *}$ \\
\hline Lines $\mathrm{x}$ testers & 4 & $26.980^{\star *}$ & $41.130^{\star *}$ & $50.702^{* *}$ & $68.941^{* *}$ \\
\hline Error & 28 & 16.554 & 15.449 & 13.576 & 16.475 \\
\hline
\end{tabular}

${ }^{*}$ and ${ }^{* *}$ Significant at $5 \%$ and $1 \%$ levels of probability, respectively.

The interactions of genotypes, parents and crosses with the two years were highly significant for all grain yield and its component traits with the except of 1000-grain weight which had insignificant mean square. Also, the interaction of parents vs crosses with years was found to be non significant for all yield traits except for No. of filled grains/panicle was highly 
significant. As well as, the interactions of genotypes, parents and crosses with the locations were highly significant for all grain yield and its component traits. P.vs C.xloc. which has insignificant values for No. of panicles/plant, significant values for 1000-grain weight and highly significant for the other studied traits. Interactions between genotypes, parents, crosses and parents vs crosses and years $x$ locations were highly significant for No.of grains/panicle and No. of filled grains /panicle traits and non significant for the others studied traits except for the interaction of crosses $x$ years $x$ locations for grain yield/ plant showed significant values.

Table 3: Combined mean square estimates from ordinary and line $x$ tester analysis for yield and its components traits over the two locations through the two years.

\begin{tabular}{|c|c|c|c|c|c|c|}
\hline Sov & d.f & $\begin{array}{l}\text { Grain yield } \\
\text { /plant }\end{array}$ & $\begin{array}{c}\text { No. of } \\
\text { panicles / plant }\end{array}$ & $\begin{array}{c}\text { No. of grains/ } \\
\text { panicle }\end{array}$ & $\begin{array}{l}\text { No. of filled } \\
\text { grains/ } \\
\text { panicle }\end{array}$ & $\begin{array}{c}\text { 1000-grain } \\
\text { weight }\end{array}$ \\
\hline Years & 1 & $61.098^{\star \star}$ & $61.519^{\star \star}$ & $91.800^{\star *}$ & $1822.141^{\star \star}$ & $1.342 \mathrm{~ns}$ \\
\hline Locations & 1 & $12024.445^{\star \star}$ & $1173.359^{\star \star}$ & $22925.467^{\star \star}$ & $114231.613^{\star \star}$ & $215.124^{\star \star}$ \\
\hline Yearsx Loc. & 1 & $2.509 \mathrm{~ns}$ & $0.001 \mathrm{~ns}$ & $3.931 \mathrm{~ns}$ & $2.069 \mathrm{~ns}$ & $0.015 \mathrm{~ns}$ \\
\hline Error & 8 & 1.576 & 0.088 & 15.776 & 8.181 & 0.035 \\
\hline Genotypes & 14 & $2320.655^{\star \star}$ & $98.235^{\star \star}$ & $11110.718^{\star \star}$ & $34634.83^{\star \star}$ & $49.916^{\star \star}$ \\
\hline \begin{tabular}{|l} 
Parents \\
\end{tabular} & 5 & $1357.478^{\star \star}$ & $106.658^{\star \star}$ & $11127.543^{\star \star}$ & $24951.749^{\star \star}$ & $56.291^{\star \star}$ \\
\hline Crosses & 8 & $321.912^{\star \star}$ & $66.415^{\star \star}$ & $6855.437^{\star \star}$ & $5834.780^{\star \star}$ & $33.682^{\star \star}$ \\
\hline Lines (L.) & 2 & $67.683^{\star \star}$ & $23.123^{\star \star}$ & $7069.256^{\star \star}$ & $4611.721^{\star \star}$ & $65.023^{\star \star}$ \\
\hline Testes (T.) & 2 & $906.785^{\star \star}$ & $110.670^{\star \star}$ & $15606.433^{\star \star}$ & $12991.333^{\star \star}$ & $33.643^{\star \star}$ \\
\hline L. $\times$ T. & 4 & $156.590^{\star \star}$ & $65.935^{\star \star}$ & $2373.030^{\star \star}$ & $2868.034^{\star \star}$ & $18.031^{\star \star}$ \\
\hline P. vs C. & 1 & $23126.484^{\star \star}$ & $310.680^{\star \star}$ & $45068.841^{\star \star}$ & $313450.135^{\star \star}$ & $147.913^{\star \star}$ \\
\hline G. $\times$ Y. & 14 & $4.126^{\star \star}$ & $3.160^{\star \star}$ & $8.594^{\star \star}$ & $120.989^{\star \star}$ & $0.184 \mathrm{~ns}$ \\
\hline P. $\times$ Y. & 5 & $2.284^{\star}$ & $3.660^{* \star}$ & $6.966^{\star \star}$ & $211.528^{\star \star}$ & $0.231 \mathrm{~ns}$ \\
\hline C. $\times Y$. & 8 & $5.538^{\star \star}$ & $3.172^{\star \star}$ & $10.592^{\star \star}$ & $17.323^{\star \star}$ & $0.174 n s$ \\
\hline L. $\times Y$. & 2 & $6.590^{\star \star}$ & $3.574^{\star}$ & $28.260^{\star \star}$ & $7.564^{\star \star}$ & $0.259 \mathrm{~ns}$ \\
\hline T. $\times Y$. & 2 & $12.590^{\star \star}$ & $4.468^{*}$ & $5.969^{\star \star}$ & $45.958^{\star \star}$ & $0.377 n s$ \\
\hline L. . T. $\times$ Y. & 4 & $1.487 n s$ & $2.323 \mathrm{~ns}$ & $4.071^{*}$ & $7.884^{\star \star}$ & $0.031 \mathrm{~ns}$ \\
\hline P. vs C.XY. & 1 & $2.040 \mathrm{~ns}$ & $0.564 \mathrm{~ns}$ & $0.750 \mathrm{~ns}$ & $497.622^{\star \star}$ & $0.029 n s$ \\
\hline G. × Loc. & 14 & $115.925^{\star \star}$ & $10.886^{\star \star}$ & $263.597^{\star \star}$ & $1158.077^{\star \star}$ & $9.265^{\star \star}$ \\
\hline P. $\times$ Loc. & 5 & $205.854^{\star \star}$ & $10.330^{\star \star}$ & $424.089^{\star \star}$ & $1268.494^{\star \star}$ & $17.023^{\star \star}$ \\
\hline C. $\times$ Loc. & 8 & $52.442^{\star \star}$ & $12.174^{\star \star}$ & $195.098^{\star \star}$ & $570.766^{\star \star}$ & $4.910^{\star \star}$ \\
\hline L. $\times$ Loc. & 2 & $62.285^{\star \star}$ & $33.035^{\star \star}$ & $400.568^{\star \star}$ & $670.722^{\star \star}$ & $1.333 \mathrm{~ns}$ \\
\hline T. $\times$ Loc. & 2 & $89.160^{\star \star}$ & $4.715^{\star \star}$ & $138.302^{\star \star}$ & $1266.038^{\star \star}$ & $16.805^{\star \star}$ \\
\hline L. $\times$ T. $\times$ Loc. & 4 & $29.162^{\star \star}$ & $5.474^{\star \star}$ & $120.762^{\star \star}$ & $173.152^{\star \star}$ & $0.751 \mathrm{~ns}$ \\
\hline P. vs C. $\times$ Loc. & 1 & $174.144^{\star \star}$ & $3.362 \mathrm{~ns}$ & $9.129^{\star \star}$ & $5304.480^{\star \star}$ & $5.315^{\star}$ \\
\hline G. $\times$ Y.×Loc. & 14 & $1.645 \mathrm{~ns}$ & $0.683 n s$ & $14.582^{\star \star}$ & $8.421^{\star \star}$ & $0.183 n s$ \\
\hline P. $\times$ Y.X Loc. & 5 & $0.913 \mathrm{~ns}$ & $0.412 \mathrm{~ns}$ & $26.655^{\star \star}$ & $12.695^{\star \star}$ & $0.145 \mathrm{~ns}$ \\
\hline C.XY.XLoc. & 8 & $2.078^{\star}$ & $0.793 \mathrm{~ns}$ & $4.535^{\star \star}$ & $4.788^{\star \star}$ & $0.213 \mathrm{~ns}$ \\
\hline L.×Y. $\times$ Loc. & 2 & $1.679 \mathrm{~ns}$ & $0.432 \mathrm{~ns}$ & $0.124 \mathrm{~ns}$ & $8.626^{\star \star}$ & $0.471 \mathrm{~ns}$ \\
\hline T. $\times$ Y. $\times$ Loc. & 2 & $5.602^{\star \star}$ & $0.647 \mathrm{~ns}$ & $12.378^{\star \star}$ & $5.375^{\star}$ & $0.023 \mathrm{~ns}$ \\
\hline L.XT.XY.x Loc. & 4 & $0.514 \mathrm{~ns}$ & $1.047 \mathrm{~ns}$ & $2.820^{\star}$ & $2.576^{\star}$ & $0.179 n s$ \\
\hline P.vs C.XY.xLoc. & 1 & $1.841 \mathrm{~ns}$ & $1.158 \mathrm{~ns}$ & $34.593^{\star \star}$ & $16.115^{\star \star}$ & $0.133 \mathrm{~ns}$ \\
\hline Error & 112 & 15.513 & 1.402 & 119.43 & 122.812 & 0.390 \\
\hline
\end{tabular}

${ }^{*}$ and ${ }^{\star \star}$ Significant at $5 \%$ and $1 \%$ levels of probability, respectively.

The results also illustrated that the general combining ability variance (GCA) for both lines and testers and specific combing ability (SCA) of lines $x$ testers showed high significance in both the two years at normal and saline 
conditions for all studied traits except for 1000-grain weight trait (GCA) for testers was non significant in saline conditions also grain yield/plant (GCA)for lines was non significant in the second year at normal condition. On the other hand, GCA of lines and testers and SCA for lines $x$ testers were highly significant for all studied traits in combined data. The interactions of years with general combining ability (GCA) of lines and testers were non significant for 1000-grain weight and highly significant and significant for the rest of yield studied traits. But, The interactions of years with (SCA) of lines $x$ testers were highly significant for No. of filled grains/panicle, significant for No. of grains/ panicle and non significant for other yield traits. This indicated that the nonadditive genetic variance is more stable for most studied traits than additive through years. The interactions of locations with both types of combining ability, (GCA) of lines and testers and SCA of lines $x$ testers were highly significant for all yield studied traits except 1000-grain weight trait which showed non significant mean squares for interactions, GSA of lines and SCA of lines $x$ testers. The interactions of locations and years with GCA of lines were non significant in all yield studied traits except for no. of filled grains /panicle which was highly significant. In the case of GCA of testers, the interaction was highly significant for No. of grains /panicle and grain yield /plant traits, significant for No. of filled grains /panicle trait and non significant for other yield studied traits. Therefore, there is no interaction between years and locations with SCA for lines $x$ testers in all studied traits except for No. of grains /panicle and No . of filled grains / panicle the interactions were significant. These results indicated that both additive and non-additive genetic variances tended to interact with environments for the significant interactions. Therefore, selection for these traits would not be effective in a single environment, but more environments would be required. This finding indicate that the additive type of gene action played a major role in the inheritance of yield and its component traits. These results were in agreement with conclusions made by Lokaprakash et al. (1991), El-Refaee (2002), El-Mowafi et al. (2003), Hammoud (2004), Abd El-Hadi and El-Mowafi (2005), Pradhan et al. (2006), Abd Allah (2008), El-Diasty et al. (2008), Shereen et al. (2009) and Nadali and Jelodar (2010).

\section{Genetic parameters:}

The estimates of genetic parameters of the studied yield and its component traits are shown in Table 4. The results cleared that the magnitude of non-additive genetic variance $\left(\sigma^{2} D\right)$ for all studied traits which were positive at the two locations in the two years. Also, the magnitude of additive genetic variance $\left(\sigma^{2} A\right)$ were positive for all studied traits in all conditions except for No. of panicles/plant in the first season at the first location. $\sigma^{2} A$ was larger than $\sigma^{2} D$ under all environments for all studied traits except for No. of panicles/plant at the two locations in the two years and yield /plant in both years of salinity location. This indicate that additive genetic variance is the master player in the inheritance of these traits.

Table 4: Estimation of genetic parameters for yield and its components traits at the two locations in the two years and the combined data over locations through years. 
Table 4: Continue.

\begin{tabular}{|l|c|c|c|c|c|c|c|c|c|c|}
\hline \multirow{2}{*}{$\begin{array}{c}\text { Genetic } \\
\text { parameters }\end{array}$} & \multicolumn{9}{|c|}{ No. of panicles/plant } & \multicolumn{5}{c|}{ No.of grains/panicle } \\
\cline { 2 - 10 } & L1 Y1 & L1Y2 & L2Y1 & L2Y2 & Comb. & L11 & L1Y2 & L2Y1 & L2Y2 & Comb. \\
\hline$\sigma^{2} \mathrm{~A}$ & 0.00 & 2.13 & 1.90 & 0.35 & 0.053 & 394.66 & 467.13 & 566.02 & 601.07 & 498.045 \\
$\sigma^{2} \mathrm{D}$ & 5.13 & 6.06 & 4.38 & 7.49 & 5.378 & 214.90 & 183.20 & 122.38 & 87.16 & 183.632 \\
D.d & 0.00 & 1.69 & 1.52 & 4.63 & 10.073 & 0.74 & 0.63 & 0.46 & 0.38 & 0.607 \\
$\sigma^{2} \mathrm{E}$ & 0.61 & 1.26 & 2.05 & 1.69 & 1.402 & 84.88 & 154.16 & 202.61 & 236.12 & 169.443 \\
$\mathrm{G}$ & 5.13 & 8.19 & 6.28 & 7.84 & 98.235 & 609.56 & 650.33 & 688.40 & 688.23 & 11110.718 \\
$\sigma^{2} \mathrm{P}$ & 5.74 & 9.45 & 8.33 & 9.53 & 99.637 & 694.43 & 804.49 & 891.01 & 924.36 & 11280.161 \\
$\mathrm{~h}^{2} \mathrm{~b}$ & 0.00 & 0.23 & 0.23 & 0.04 & 0.676 & 0.57 & 0.58 & 0.64 & 0.65 & 0.823 \\
$\mathrm{~h}^{2} \mathrm{n}$ & 0.87 & 0.87 & 0.75 & 0.82 & 0.007 & 0.88 & 0.81 & 0.77 & 0.75 & 0.601 \\
$\sigma^{2} \mathrm{AY}$ & - & - & - & - & 0.189 & - & - & - & - & 1.449 \\
$\sigma^{2} \mathrm{AL}$ & - & - & - & - & 1.489 & - & - & - & - & 16.519 \\
$\sigma^{2} \mathrm{AYL}$ & - & - & - & - & -0.338 & - & - & - & - & 2.287 \\
$\sigma^{2} \mathrm{DY}$ & - & - & - & - & 0.154 & - & - & - & - & -27.562 \\
$\sigma^{2} \mathrm{DL}$ & - & - & - & - & 0.679 & - & - & - & - & -8.114 \\
$\sigma^{2} \mathrm{DYL}$ & - & - & - & - & -0.118 & - & - & - & - & -55.541 \\
\hline
\end{tabular}

Table 4: Continue.

\begin{tabular}{|c|c|c|c|c|c|c|}
\hline \multirow{2}{*}{\multicolumn{2}{|c|}{\begin{tabular}{|c|}
\multicolumn{2}{|c|}{ Genetic } \\
Generlc \\
parameters \\
parfameters \\
$\sigma^{2}$
\end{tabular}}} & \multicolumn{5}{|c|}{ Ho of filled arainstplant Grain yietd/plaptog arain weight } \\
\hline & & 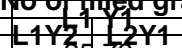 & t2y ${ }^{2}$ comb. & $2 Y 1$ & $4142242 Y 1$ & L2Y \\
\hline & 657.31 & $589.67 \cdot 165.42$ & 88.04 .05329 .639 & 3.34 & 3.056 .03 .12 & 1.378 .3691 .739 \\
\hline & 140.34 & 120.43 .489 .37 & 303.3256228 .769 & & $2.17^{17} 48.94$ & 0.841 .7561 .470 \\
\hline$\Phi$ & 0.46 & 0.450 .37 .32 & 1.80 .430 .833 & 10.75 & 0.841 .700 .92 & 0.780 .8000 .919 \\
\hline & 109.19 & 101.766 .553 .54 & 126.1/6.6.45122.812 & 13.5 & 0.2116 .48 .60 & 0.390 \\
\hline & 797.65 & 710.109 .854 .80 & 39156.634634 .830 & 15.80 & 5.2323 .52 .06 & 2.2B20.6\$9.916 \\
\hline & 906.85 & 811.865 .808 .33 & $518,17.034757 .642$ & 3\$.59 & 5.4439 .99 .67 & 2.23336.1@8.306 \\
\hline & 0.73 & 0.730 .58 .27 & $0.17 .66 \quad 0.785$ & 0 क्रक्रि & $0.560 .15^{0.42}$ & $0.520 .633^{0.790}$ \\
\hline & - & $-0.64=$ & -0.780 .463 & 0.59 & $-0.59=$ & - $0.386^{0.428}$ \\
\hline $2 A$ & - & & $-\quad-\quad 2.097$ & & & - 0.9000 .032 \\
\hline & - & - & 88.359 & - & - & -51730.924 \\
\hline & - & - & 2.950 & - & - & 0.045 \\
\hline & - & - & -19.155 & C. & - & $4-0.060$ \\
\hline$\sigma^{2} D Q Y$ & - & - & 8.390 & -- & - & --2.3380 .060 \\
\hline$\sigma^{2} D D L$ & - & - & -40.079 & -- & - & $-2.275-0.070$ \\
\hline \multicolumn{2}{|l|}{$\sigma^{2} D Y L$} & 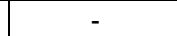 & - & - & - & -5.000 \\
\hline
\end{tabular}

Similar results were obtained by El-Mowafi (1988), El-Mowafi (1994), Hammoud (1996), Attia (2001), El-Mowafi (2001), El-Refaee (2002) Sarker et al. (2002), El-Mowafi et al. (2003) Abd Allah (2008), Shereen et al. (2009) and Nadali and Jelodar (2010). On the other hand, the estimation of genetic parameters from the combined analysis showed that the additive genetic variance $\left(\sigma^{2} A\right)$ were positive and larger than those of non-additive genetic variance $\left(\sigma^{2} D\right)$ for all yield and its components traits. These result accurate the single analysis results and introduce the prove that the additive effects play the major role in the expression of yield traits except for No. of panicles/plant trait which was under control of dominance effects and the over-dominance play the big role in its expression.

Genetic parameters by years, locations and years $x$ locations interactions also revealed that the magnitude of additive by locations $\left(\sigma^{2} A \times L\right)$ were positive and larger than the corresponding values of non-additive by locations $\left(\sigma^{2} D \times L\right)$ which were positive for all yield studied traits except for 
No. of grains/panicle trait. While, the magnitude of additive by years $\left(\sigma^{2} A \times Y\right)$ were positive and larger than non-additive by years $\left(\sigma^{2} D \times Y\right)$ which recorded negative values for all yield studied traits except for No. of panicles/plant. For the $\sigma^{2} A \times Y \times L$ effects all traits revealed positive values except for No. of panicles /plant trait which exhibited negative magnitude value while, $\sigma^{2} D \times Y x$ $L$ effects revealed negative values for all studied traits. These result suggests that the non-additive effects are more stable over different environments than the additive effects.

The estimated values of heritability at the two locations in the two years and from the combined data over them revealed closed equal $\mathbf{h}^{2}$ values to $\mathbf{h}_{\mathbf{b}}{ }_{\mathbf{b}}$ in some traits at some environments because of the zero value of dominance effects. The highest estimate of combined narrow sense heritability was observed in the case of No. of grains/panicle $(0.601)$ and that confirms the big role to additive effects while, the lowest recorded in No. of panicles /plant (0.007) and that due to the highly influence of ecological conditions. On the other hand, the estimates of heritability in broad sense ranged from 0.823 for No. of grains/panicle to 0.633 in yield/plant. However, these results are in general agreement with those reported by Kuo and Liu (1987).

\section{Estimation of GCA effects:}

The estimated values of general combining ability effects (gi) for parental lines (CMS and restorer lines) for yield and its components in the two years at the two locations and their combined data are presented in Table 5. The restorer line Giza178R exhibited highly significant positive GCA effects for grain yield/plant trait in normal media and from the combined data, proving to be good combiners for this trait. In the same time, the restorer Giza181R exhibited highly significant positive GCA effects at all environments and from the combined data. The former cultivars which proved to be good combiners. For No. of panicles/plant trait, the restorer Giza181R revealed highly significant positive GCA effects at all environmental and from the combined data, this finding indicate that is excellent combiners at normal and saline environments. While, the female line IR69625A and the tester line Giza178R recorded highly significant positive GCA effects under normal environment and from the combined data.

Table 5: Estimation of general combining ability effects ( $\mathrm{gi}$ ) for lines and testers at the two locations in the two years and the combined data over locations in years for yield and its components traits. Estimation of SCA effects: 


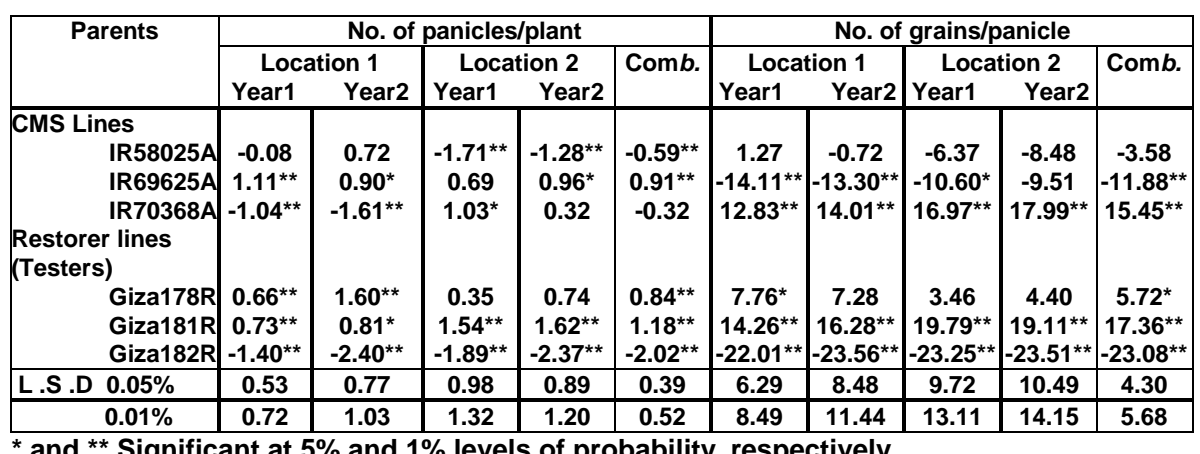

Table 5: Continue.

\begin{tabular}{|c|c|c|c|c|c|c|c|c|c|c|}
\hline \multirow[t]{3}{*}{ Parents } & \multicolumn{5}{|c|}{ No. of filled grains/panicle } & \multicolumn{5}{|c|}{ 1000-grain weight } \\
\hline & \multicolumn{2}{|c|}{ Location 1} & \multicolumn{2}{|c|}{ Location 2} & \multirow{2}{*}{ Comb. } & \multicolumn{2}{|c|}{ Location 1} & \multicolumn{2}{|c|}{ Location 2} & \multirow{2}{*}{ Comb. } \\
\hline & Year1 & Year2 & Year1 & Year2 & & Year1 & Year2 & Year1 & Year2 & \\
\hline CMS Lines & & & & & & & & & & \\
\hline IR58025A & -3.60 & -3.35 & $-13.26^{\star \star}$ & $-11.43^{\star \star}$ & $-7.91^{\star \star}$ & $-1.73^{\star \star}$ & $-1.34^{\star *}$ & $-1.56^{\star \star}$ & $-1.57^{\star \star}$ & $-1.55^{\star \star}$ \\
\hline IR69625A & $-8.73^{\star \star}$ & $-9.75^{\star \star}$ & -0.67 & -1.07 & $-5.05^{\star \star}$ & $0.69^{\star \star}$ & $0.34^{\star}$ & $0.84^{\star \star}$ & $0.99^{\star \star}$ & $0.72^{\star \star}$ \\
\hline IR70368A & $12.33^{\star \star}$ & $13.10^{\star \star}$ & $13.92^{\star \star}$ & $12.50^{\star \star}$ & $12.96^{\star \star}$ & $1.04^{\star \star}$ & $0.99^{\star \star}$ & $0.72^{\star \star}$ & $0.58^{\star}$ & $0.83^{\star \star}$ \\
\hline $\begin{array}{l}\text { Restorer lines } \\
\text { (Testers) }\end{array}$ & & & & & & & & & & \\
\hline Giza178R & $7.64^{\star}$ & $8.60^{\star}$ & -0.76 & 1.39 & $4.22^{\star}$ & $-0.85^{\star \star}$ & $-0.86^{\star \star}$ & -0.12 & -0.07 & $-0.48^{\star \star}$ \\
\hline Giza181R & $20.89^{\star \star}$ & $18.01^{\star \star}$ & $14.77^{\star \star}$ & $12.46^{\star \star}$ & $16.53^{\star \star}$ & $-0.93^{\star \star}$ & $-1.17^{\star *}$ & -0.13 & -0.32 & $-0.64^{\star *}$ \\
\hline Giza182R & $-2853^{\star *}$ & $-26.62^{\star \star}$ & $-14.01^{\star \star}$ & $-13.84^{\star \star}$ & $-20.75^{\star \star}$ & $1.78^{\star \star}$ & $2.03^{\star \star}$ & 0.26 & 0.39 & $1.11^{\star \star}$ \\
\hline L.S.D $0.05 \%$ & 7.13 & 6.89 & 8.46 & 7.69 & 3.66 & 0.39 & 0.31 & 0.53 & 0.44 & 0.21 \\
\hline $0.01 \%$ & 9.62 & 9.29 & 11.41 & 10.37 & 4.83 & 0.53 & 0.42 & 0.72 & 0.60 & 0.27 \\
\hline
\end{tabular}

${ }^{*}$ and ${ }^{\star *}$ Significant at $5 \%$ and $1 \%$ levels of probability, respectively

Table 5: Continue.

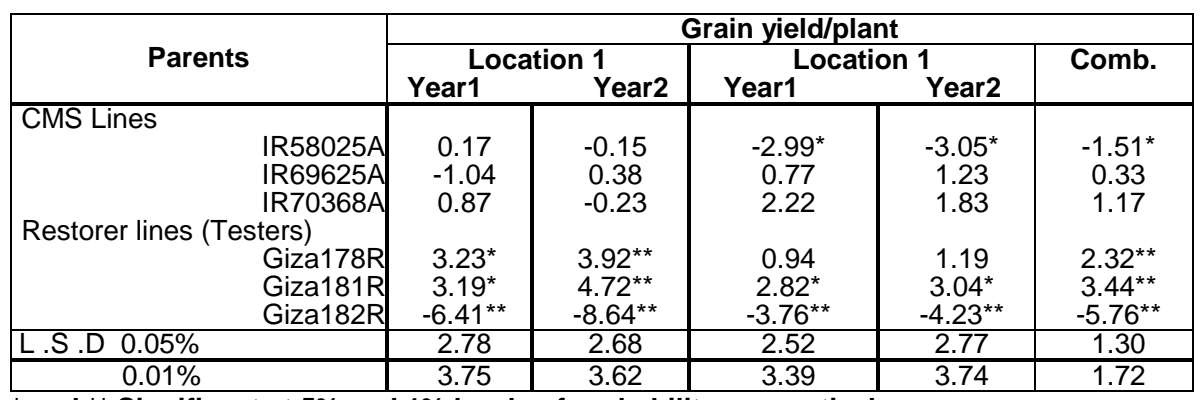

${ }^{*}$ and ${ }^{* *}$ Significant at $5 \%$ and $1 \%$ levels of probability, respectively.

The results indicate that both of No. of grains/panicle and No. of filled grains/panicle traits tack the same direction, the CMS line IR70368A and the tester line Giza181 showed highly significant positive GCA effects in each year at each location and from the combined data. So these genotypes will be successful in breeding hybrids with high number of total and filled grains at both normal and saline environments.

Concerning 1000-grain weight traits, the results indicated that the two CMS lines, IR69625A and IR70368A showed highly significant and positive 
GCA effects at single and combined data. It could be also concluded that these two CMS lines were excellent combiners for 1000 -grain weight trait. It could be of practical interest in a hybrid rice breeding program towards developing high yielding genotypes under salinity and normal environments. Also, the restorer line Giza182R exhibited high positive GCA effect at normal and from the combined data.

The estimated values of specific combining ability effects $\left(S_{i j}\right)$ for yield and its component traits in years at locations and for the combined data are presented in Table 6 . The results revealed that all $F_{1}$ hybrids showed insignificant effects for grain yield /plant trait at the two locations in the two years and their combined data except for the hybrids IR58025A x Giza182R and IR70368A x Giza181R, which showed highly significance SCA effects from the combined data. The results also indicated that, four $F_{1}$ hybrids out of the nine hybrid combinations showed significant $S_{i j}$ for No. of panicles/plant trait from the combined data. In the same time, the hybrid combination IR58025A x Giza182R consider good combination under all conditions. But the combination IR69625A x G181R was the best under saline media and IR70368A $\times$ Giza178R was good at the normal conditions.

Concerning No. of grain/panicle and filled grains/panicle traits, the results indicated that most of $F_{1}$ hybrid showed significant positive $S_{i j}$ at the two locations in the two years. However, four and two hybrids recorded highly significant positive $S_{i j}$ from the combined data for No. of grains/panicle and filled grains/panicle, respectively. Furthermore, the hybrid combination IR58025A x Giza178R is considered as best combination for No. of grains/panicle trait. While, the hybrid IR70368A x Giza181R was the best combination for No. of filled grains/panicle.

The results also illustrated that three $F_{1}$ hybrids exhibited highly significant desirable $S_{i j}$ from combined data for 1000-grain weight trait, these hybrids were IR58025A x Giza182R, IR69625A x Giza178R and IR70368A x Giza181R. Whereas, the hybrid IR58025A x Giza182R scored high significant effects under all conditions. The hybrids IR69625A x Giza178R and IR70368A x Giza181R were exhibited high SCA effects at normal condition.

It could be mentioned that the significant positive values of $\mathrm{S}_{\mathrm{ij}}$ which were observed revealed the possibility of using them in hybrid rice breeding program.Generally, the results revealed that the $F_{1}$ hybrids IR70368A $x$ Giza181R and IR58025A x Giza182 were the best $S_{i j}$ under all conditions for all studied yield and its component traits.

Table 6: Estimation of specific combining ability effects (Sij) for nine hybrids at the two locations in the two years and their combined data over locations in years for yield and its components traits. 


\begin{tabular}{|c|c|c|c|c|c|c|c|c|c|c|}
\hline \multirow[t]{2}{*}{ Hybrids } & \multicolumn{5}{|c|}{ No. of panicles/plant } & \multicolumn{5}{|c|}{ No. of grains/panicle } \\
\hline & \multicolumn{2}{|c|}{\begin{tabular}{|cc|}
\multicolumn{2}{|c|}{ Location 1 } \\
Year1 & Year2
\end{tabular}} & \multicolumn{2}{|c|}{\begin{tabular}{|cc|}
\multicolumn{2}{c|}{ Location 2} \\
Year1 $\quad$ Year2 \\
\end{tabular}} & Comb. & \multicolumn{2}{|c|}{ Location 1} & \multicolumn{2}{|c|}{\begin{tabular}{|lr|}
\multicolumn{2}{|c|}{ Location 2} \\
Year1 & Year2 \\
\end{tabular}} & Comb. \\
\hline R58025AxGiza178R & $-1.56^{\star \star}$ & $-1.62^{\star}$ & -0.50 & -0.86 & $-1.13^{\star \star}$ & $11.09^{*}$ & 11.36 & 10.65 & 9.06 & $10.54^{\star \star}$ \\
\hline xGiza181R & $-1.14^{\star}$ & -0.76 & $-2.22^{\star}$ & $-2.70^{\star \star}$ & $-1.96^{\star \star}$ & $-19.08^{\star \star} \mid$ & $-19.30^{*}$ & $-17.98^{\star}$ & -16.72 & $-18.27^{\star \star}$ \\
\hline xGiza182R & $2.70^{\star \star}$ & $3.38^{\star *}$ & $2.71^{\star *}$ & $3.56^{\star \star}$ & $3.09^{\star \star}$ & 7.99 & 7.94 & 7.33 & 7.67 & $7.73^{\star}$ \\
\hline R69625AxGiza178R & -0.35 & 0.67 & 0.94 & 0.78 & 0.5 & 0.27 & -0.59 & -4.06 & -3.24 & -1.91 \\
\hline xGiza181R & 0.64 & 1.13 & 0.71 & $1.63^{\star}$ & & 10.00 & 8.94 & 6.17 & 5.08 & $7.55^{\star}$ \\
\hline xGiza182R & -0.29 & $-1.80^{\star}$ & -1.65 & $-2.41^{\star \star}$ & $-1.54^{\star \star}$ & -10.27 & -8.35 & -2.11 & -1.83 & -5.64 \\
\hline RT0368AxGiza178R & $1.91^{\star \star}$ & 0.95 & -0.44 & 0.08 & $0.62^{\star}$ & -11.36 & -10.77 & -6.59 & -5.81 & $-8.63^{\star}$ \\
\hline xGiza181R & 0.50 & 0.64 & 1.50 & 1.07 & 0.9 & 9.08 & 10.36 & 11.81 & 11.64 & $10.72^{\star \star}$ \\
\hline xGiza182R & $\left|-2.41^{\star \star}\right|$ & $-1.59^{\star}$ & -1.06 & -1.14 & $-1.55^{\star \star}$ & 2.28 & 0.41 & -5.21 & -5.83 & -2.09 \\
\hline L.S.D $0.05 \%$ & 0.93 & 1.33 & 1.69 & 1.54 & 0.68 & 10.89 & 14.68 & 16.83 & 18.17 & 7.44 \\
\hline $0.01 \%$ & 1.25 & 1.79 & 2.28 & 2.07 & 0.90 & 14.70 & 19.81 & 22.71 & 24.51 & 9.83 \\
\hline
\end{tabular}

** Significant at $5 \%$ and $1 \%$ levels of probability, respectively.

Table 6: Continue.

\begin{tabular}{|c|c|c|c|c|c|c|c|c|c|c|}
\hline \multirow[t]{3}{*}{ Hybrids } & \multicolumn{5}{|c|}{ No. of filled grains/panicle } & \multicolumn{5}{|c|}{ 1000- grain weight } \\
\hline & \multicolumn{2}{|c|}{ Location 1} & \multicolumn{2}{|c|}{ Location 2} & \multirow{2}{*}{ Comb. } & \multicolumn{2}{|c|}{ Location 1} & \multicolumn{2}{|c|}{ Location 2} & \multirow[t]{2}{*}{ Comb. } \\
\hline & Year1 & Year2 & Year1 & Year2 & & Year1 & Year2 & Year1 & Year2 & \\
\hline IR58025AxGiza178R & 11.40 & 10.72 & 10.54 & 10.76 & $10.58^{* *}$ & $-0.88^{\star}$ & -0.03 & -0.87 & $-0.89^{\star}$ & $-0.92^{\star \star}$ \\
\hline xGiza181R & $-13.38^{*}$ & $-13.36^{\star}$ & $-18.68^{\star}$ & $-20.21^{\star \star}$ & $-16.41^{\star \star}$ & $-0.88^{\star}$ & $-0.83^{\star \star}$ & -0.47 & -0.32 & $-0.63^{\star \star}$ \\
\hline xGiza182R & 1.98 & 2.64 & 8.13 & 9.46 & 5.55 & $1.75^{\star \star}$ & $1.86^{\star \star}$ & $1.35^{\star \star}$ & $1.21^{\star \star}$ & $1.54^{\star \star}$ \\
\hline 69625AxGiza178R & 3.13 & 1.75 & 8.46 & 6.86 & 5.05 & $0.98^{\star \star}$ & $0.92^{\star \star}$ & 0.74 & $0.78^{\star}$ & $0.86^{\star \star}$ \\
\hline xGiza181R & 3.22 & 5.07 & 1.10 & 2.19 & 2.90 & 0.01 & -0.20 & -0.06 & 0.03 & -0.05 \\
\hline xGiza182R & -6.36 & -6.83 & -9.56 & -9.04 & $-7.95^{\star}$ & $-0.99^{\star *}$ & $-0.72^{\star}$ & -0.69 & $-0.81^{*}$ & $-0.80^{\star \star}$ \\
\hline RT0368AxGiza178P & $-14.53^{\star}$ & $-12.47^{\star}$ & $-19.00^{*}$ & $-17.61^{*}$ & $-15.90^{\star \star}$ & -0.10 & 0.11 & 0.13 & 0.11 & 0.06 \\
\hline xGiza181R & 10.16 & 8.29 & $17.58^{\star}$ & $18.02^{\star \star}$ & $13.51^{\star \star}$ & $0.86^{\star}$ & $1.03^{\star \star}$ & 0.53 & 0.30 & $0.68^{\star \star}$ \\
\hline xGiza182R & 4.38 & 4.19 & 1.42 & -0.41 & 2.39 & $-0.76^{\star}$ & $-1.14^{\star \star}$ & -0.66 & -0.41 & $-0.74^{\star *}$ \\
\hline L.S.D $0.05 \%$ & 12.36 & 11.93 & 14.65 & 13.31 & 6.33 & 0.68 & 0.54 & 0.92 & 0.77 & 0.36 \\
\hline $0.01 \%$ & 16.67 & 16.09 & 19.77 & 17.96 & 8.37 & 0.91 & 0.73 & 1.24 & 1.04 & 0.47 \\
\hline
\end{tabular}

${ }^{*}$ and ${ }^{\star *}$ Significant at $5 \%$ and $1 \%$ levels of probability, respectively.

Table 6: Continue.

\begin{tabular}{|c|c|c|c|c|c|}
\hline \multirow[t]{3}{*}{ Hybrids } & \multicolumn{5}{|c|}{ Grain yield/plant } \\
\hline & \multicolumn{2}{|c|}{ Location 1} & \multicolumn{2}{|c|}{ Location 2} & \multirow[t]{2}{*}{ Comb. } \\
\hline & Year1 & Year2 & Year1 & Year2 & \\
\hline IR58025A xGiza178R & 0.21 & -0.26 & 0.71 & 0.14 & 0.09 \\
\hline xGiza181R & -2.80 & -3.48 & $-4.86^{\star}$ & $-4.92^{*}$ & $-3.95^{\star *}$ \\
\hline xGiza182R & 3.01 & 3.75 & 3.88 & 4.79 & $3.86^{\star *}$ \\
\hline IR69625A xGiza178R & -1.05 & -1.08 & 1.39 & 2.34 & 0.40 \\
\hline xGiza181R & 0.70 & 0.69 & 0.47 & 0.29 & 0.54 \\
\hline xGiza182R & 0.35 & 0.40 & -1.87 & -2.63 & -0.94 \\
\hline IR70368A xGiza178R & 1.26 & 1.35 & -2.10 & -2.48 & -0.49 \\
\hline xGiza181R & 2.11 & 2.80 & 4.11 & 4.63 & $3.41^{* *}$ \\
\hline xGiza182R & -3.36 & -4.14 & -2.01 & -2.15 & $-2.92^{*}$ \\
\hline L.S.D $0.05 \%$ & 4.81 & 4.65 & 4.36 & 4.80 & 2.25 \\
\hline $0.01 \%$ & 6.49 & 6.27 & 5.88 & 6.48 & 2.98 \\
\hline
\end{tabular}

${ }^{*}$ and ${ }^{* \star}$ Significant at $5 \%$ and $1 \%$ levels of probability, respectively.

\section{REFERENCES}


Abd Allah, R. M. (2008). Genetical and morphological studies on environmental genetic and cytoplasmic male sterility lines in rice. M.Sc. Thesis, Fac. of Agric. Mansoura Univ. Egypt.

Abd El-Hadi, A. H. and H.F.El- Mowafi ( 2005). Combining ability analysis of the maintainer and restorer lines for cytoplasmic male sterility (CMS) system of hybrid rice. J.Agric.Res.,83(5A):183-196.

Attia, K. A. (2001). Evaluation and RAPD analysis of photo-thermosensitive genetic male sterile lines in Indica rice (Oryza sativa L.). M.Sc. Thesis, Institute of Genetics and Plant Breeding.

Bernstein, L.; L.E. Francois and R.A. Clark (1974). Interactive effects of salinity and fertility on yields of grains and vegetables. Agron. J. 66:412 421.

El-Diasty, Z. M.; H. F. El-Mowafi; M. S. Hamada and R. M. Abd Allah (2008). Genetic studies on photo-thermo-sensitive genic male sterility (P/TGMS) and its utilization in rice breeding. J. Agric. Sci. Mansoura Univ., 33(5): 3391-3404

El-Mowafi, H.F. (1988). Breeding studies on some traits of crosses and cultivated and induced rice lines. M.Sc. Thesis, Fac. of Agric., Kafr ElSheikh, Tanta Univ., Egypt.

El-Mowafi, H.F. (1994). Studies on rice breeding. Ph.D. Thesis, Fac. of Agric., Kafr El-Sheikh Tanta Univ., Egypt.

El-Mowafi, H.F. (2001). Combining ability analysis for some cytoplasmic male sterile and restorer rice lines under Egyptian conditions. Egypt. J. Appl. Sci., 16(2): 25-51.

El-Mowafi, H. F.; A. O. Bastswisi ; A. F. Abd El-Khalek; K. A. Attia and R. A. El-Namaky (2009). Hybrid rice technology in Egypt. The $5^{\text {th }}$ International symposium on hybrid rice. 11- 15 Sept. 2008, Changcha, China, in press.

El-Mowafi, H.F.; A.O. Bastawisi; M.I. Abo-Youssef and F.U. Zanan (2003). Exploitation of rice heterosis under Egyptian conditions. $10^{\text {th }}$ Nat. Conf. Agron., 7-10 Oct., 2003. Suez Canal Univ. Fac. of Env. Agric. Sci., ElArish 133-159.

El-Refaee, Y.Z.E. (2002). Genetical and biochemical studies on heterosis and combining ability in rice. M.Sc. Thesis, Fac. of Agric., Tanta Univ., Kafr El-Sheikh, Egypt.

Flowers, T.J. and A.R. Yeo (1981). Variability in the resistance of sodium chloride salinity within rice (Oryza sativa L.) varieties. New Phytol. 88:363 373.

Greenway, H. and R. Munns. (1980). Mechanisms of salt tolerance in nonhalophytes. Annu. Rev. Plant Physiol. 31:149 -190.

Hammoud, S.A.M. (1996). Breeding studies on some rice characters. M.Sc. Thesis. Fac. of Agric., Menoufiya Univ., Egypt.

Hammoud, S.A.M. (2004). Inheritance of some quantitative characters in rice (Oryza sativa, L.). Ph.D. Thesis, Fac. of Agric., Minufiya Univ., Egypt.

Heenan, D.P.; LU. Lewin and D.W. McCaffery (1988). Salinity tolerance in rice varieties at different growth stages. Aust. J. Exp. Agric. 28:343 349. 
Jacoby, B. (1994). Mechanisms involved in salt tolerance by plants. P. 97 123. In M. Pessarakli (ed.) Hand book of Plant and Crop Stress. Marcel Dekker, New York.

Kaddah, M.I. (1963). Salinity effects on growth of rice at the seedling and inflorescence stages of development. Soil Sci. 96:105 -111.

Kempthorne, O. (1957). An Introduction to Genetic Statistics. John Wiley and Sons Inc., New York, 458-471.

Khatun, S.; CA. Rizzo and I.J. Flowers (1995). Genotypic variation in the effect of salinity on fertility in rice. Plant Soil 173:239 - 250.

Kuo, Y.C. and C. Liu (1987). Genetic studies on large grain rice. IIInheritance of heading date, plant height, panicle numbers and spikelets number. J. Agric. Res. of China. 35(1): 1-10.

Lokaprakash, R.; G. Shivashankar; M. Mahaderappa; B.T. Shankaregowda and R.S. Kulkami (1991). Combining ability for yield and its components in rice. Oryza 28(3): 319-322 (Cited from Rice Abstracts. 1995 Vol. 18, No. 1).

Munns, R. and A. Termaat (1986). Whole-plant responses to salinity. Aust. J. Plant Physiol. 13:143 -160.

Nadali B. and N. B. Jelodar (2010). Heterosis and combining ability analysis for yield and related-yield traits in hybrid rice. International Journal of Biology, 2 (2): 222-231.

Pearson, G. A. and L. Bernstein. (1959). Salinity effects at several growth stages of rice. Agron. J. 51:654 - 657.

Pradhan, S. K. ; L. K. Bose and Jitendriya-Meher (2006). Studies on gene action and combining ability analysis in basmati rice. J. of Central European Agriculture. 7(2): 267-272 .

Sajjad, M.S. (1984). Effect of increased salt stress on yield and yield components in rice. Pak. J. Sci. Ind. Res. 27:292 294.

Sarker, U.; P. S. Biswas; B. Prasad and M.M. A. Khaleque (2002). Heterosis and genetic analysis in rice hybrids. Pakistan Journal of Biological Sciences 5 (1): 1-5.

Shereen, A.; S. Mumtaz; S. Raza; M.A. Khan and S. Solangi (2009). Salinity effects on seedling growth and yield components of different inbred rice lines. Pak. J. Bol., 37 (1): 131-139. 
Abd El - Maksoud, M. M. et al.

دراسات وراثية علي القدرة على التآلف لصفات المحصول ومكوناتهـه تحت كل من التن

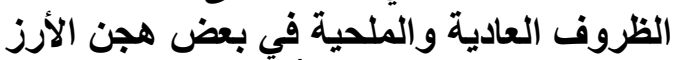

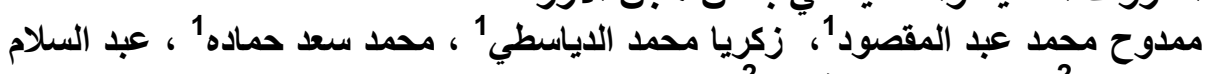

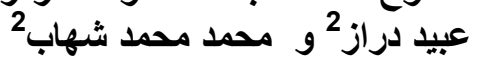

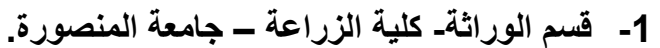
2- مركز البحوث و التدريب في الأرز - سخا ـ مصر .

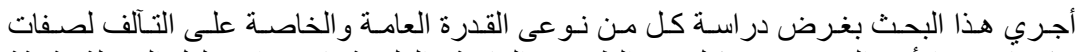

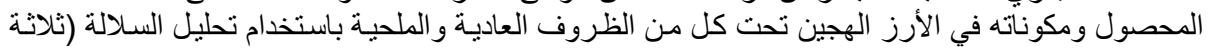

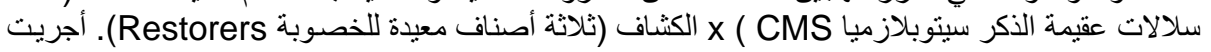

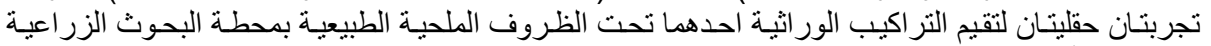

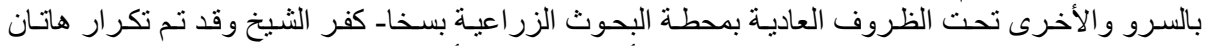

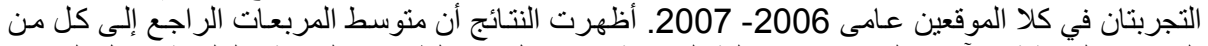

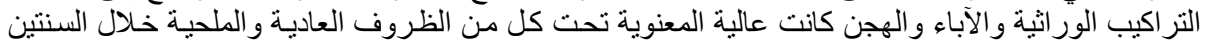

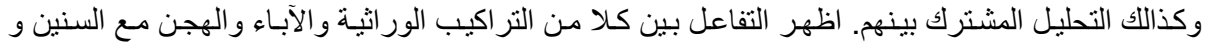

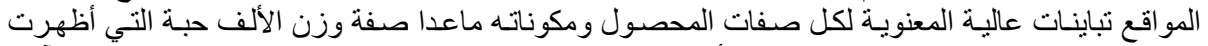

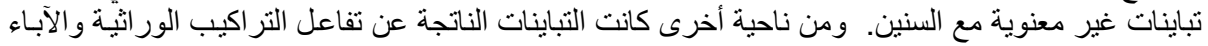

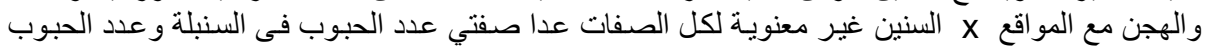
الممتلئة للسنبلة التي كانت عالية المنئ المعنوية.

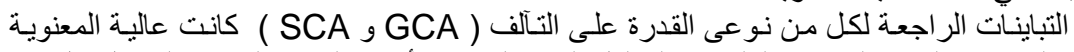

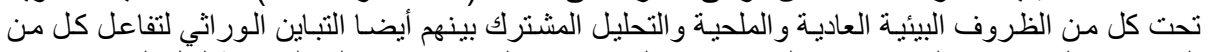

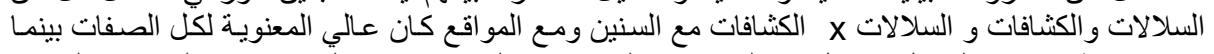

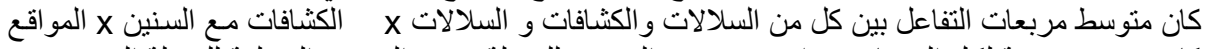

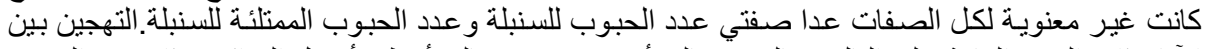

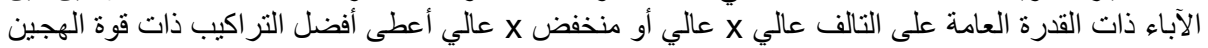

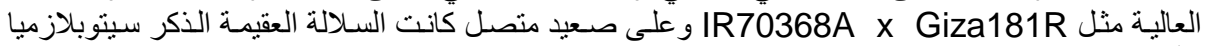

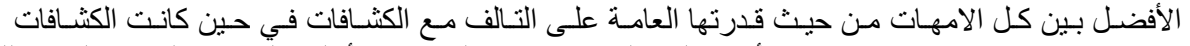
فان Giza181R وGiza182R

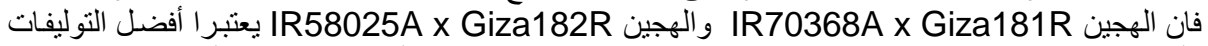

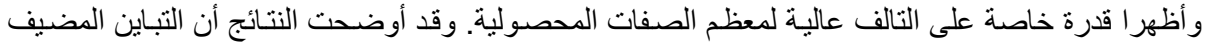

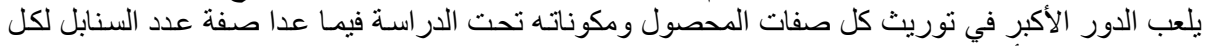

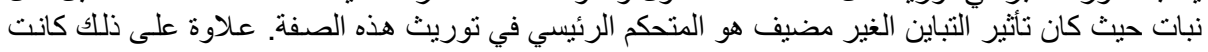

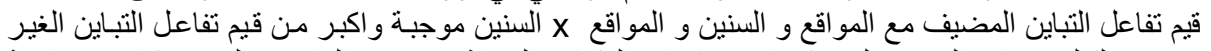

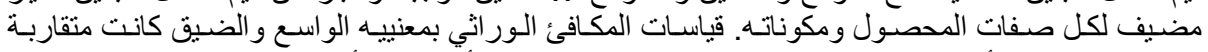

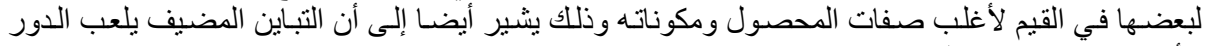
الأكبر في توارث هذه الصغ لأب الصفات.

كلية الزراعة - جامعة المنصورة كلية الزراعة - جامعة كفر الثيخ

\author{
قام بتحكيم البحث

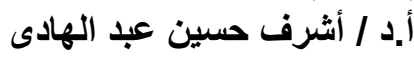 \\ أ.د / أد / محمد سيد عبد المجيد عبد المادي
}


J. Agric. Chemistry and Biotechnology, Mans. Univ., Vol. 1 (9): 497 - 510, 2010 
J. Agric. Chemistry and Biotechnology, Mans. Univ., Vol. 1 (9): 497 - 510, 2010 
J. Agric. Chemistry and Biotechnology, Mans. Univ., Vol. 1 (9), September, 2010 
J. Agric. Chemistry and Biotechnology, Mans. Univ., Vol. 1 (9): 497 - 510, 2010 
J. Agric. Chemistry and Biotechnology, Mans. Univ., Vol. 1 (9): 497 - 510, 2010 
Abd El - Maksoud, M. M. et al. 